\title{
Culture and Nutrition of Some Apochlorotic Diatoms of the Genus Nitzschia
}

\author{
By JOYCE LEWIN \\ Department of Oceanography, University of Washington, Seattle, \\ Washington, U.S.A. \\ AND R. A. LEWIN \\ Scripps Institution of Oceanography, University of California, \\ La Jolla, California, U.S.A.
}

(Accepted for publication 11 October 1966)

\begin{abstract}
SUMMARY
Three distinct species of the genus Nitzschia, lacking chloroplasts and therefore obligately heterotrophic, were isolated in pure culture from various marine shores. The organisms reproduced rapidly in a defined medium based on an artificial sea water supplemented with mineral nutrients, thiamine and cobalamin. Lactate or succinate served as sole organic carbon source for all three species; two of the species also used glucose or glutamate. Two of the species were identified as $N$. putrida Benecke and $N$. leucosigma Benecke, respectively. The third organism appears to be a new species, here named N. alba.
\end{abstract}

\section{INTRODUCTION}

Almost all diatoms are cápable of photosynthesis, but of these some can also grow heterotrophically by utilizing certain organic carbon substrates (Lewin \& Lewin, 1960). A very few species, however, lack photosynthetic pigments and are therefore obligately heterotrophic. As pointed out by Benecke (1900) and Pringsheim (1951, 1956, 1963), 'colourless' (i.e. apochlorotic) diatoms are not uncommon in marine littoral habitats, especially on decaying seaweeds; none has been reported from a freshwater habitat. Two species were described by Benecke: Nitzschia putrida (with which he identified Synedra hyalina Provazek) and $N$. leucosigma. We have isolated several clones of colourless diatoms, clearly assignable to three distinct species, one hitherto undescribed. We present some information on the nutrition of these organisms, and a taxonomic description of the new species.

\section{METHODS}

Cultures of colourless diatoms were isolated from various habitats on marine shores (see Table 1). Fragments of source material were distributed on the surface of a $1 \%$ agar medium in Petri dishes. The medium, prepared with natural sea water, was supplemented with $\mathrm{KNO}_{3}, \mathrm{~K}_{2} \mathrm{HPO}_{4}$ and Tryptone (Difco), $0 \cdot 2 \mathrm{~g} . / 1$ each. The addition of a mixture of pencillin $\left(10^{6}\right.$ i.u./1.) and streptomycin sulphate $(100 \mathrm{mg} . / \mathrm{l})$ was helpful in suppressing the growth of bacteria, but was not essential, since the diatoms tended to free themselves of contaminant organisms by their own movement over the 
agar surface. Like Richter (1909), Wagner (1934) and Pringsheim (1951), we encountered little difficulty in establishing pure bacteria-free clones by picking individual diatoms and transferring them successively to fresh sterile media.

A basal medium of the following composition was used to replace sea water by a defined mixture of nutrient salts (g.): $\mathrm{NaCl}, 20 \cdot 0 ; \mathrm{MgSO}_{4} \cdot 7 \mathrm{H}_{2} \mathrm{O}, 5 \cdot 0 ; \mathrm{CaCl}_{2} \cdot 2 \mathrm{H}_{2} \mathrm{O}$, $1 \cdot 0 ; \mathrm{KCl}, 1 \cdot 0$; sodium glycerophosphate, $0 \cdot 1 ; \mathrm{Na}_{2} \mathrm{SiO}_{3} .9 \mathrm{H}_{2} \mathrm{O}, 0 \cdot 1 ; \mathrm{B}, \mathrm{Fe}, \mathrm{Mn}, 0.5 \mathrm{mg}$. (of each element); $\mathrm{Co}, \mathrm{Cu}, \mathrm{Mo}$ and $\mathrm{Zn}, 0.01 \mathrm{mg}$. (of each element); distilled water, 1.0 l. The addition of tris buffer (Sigma; $1 \mathrm{~g} . / \mathrm{l}$.) served to stabilize the $\mathrm{pH}$ value.

Monosodium glutamate and sodium lactate ( $60 \%$, as syrup) were purchased from Fisher Scientific Co., as were most other salts used.

Media were sterilized by autoclaving at $120^{\circ}$ for $15 \mathrm{~min}$.; glucose was autoclaved separately and added aseptically.

Erlenmeyer flasks $(125 \mathrm{ml}$.) containing $50 \mathrm{ml}$. medium were used for the nutritional studies. Growth $\left(\right.$ at $30^{\circ}$ ) was accelerated by shaking the cultures.

Table 1. Sources of strains of apochlorotic marine diatoms (Nitzschia spp.)

\begin{tabular}{lccll}
\multicolumn{1}{c}{ Species } & Strain & $\begin{array}{c}\text { Date of } \\
\text { isolation }\end{array}$ & \multicolumn{1}{c}{ Locality } & \multicolumn{1}{c}{ Substrate } \\
Nitzschia alba & (Watson) & 1958 & Woods Hole, Mass., U.S.A. & Sargassum \\
& $81-\mathrm{M}$ & 1958 & Woods Hole, Mass., U.S.A. & Zostera \\
& & 1962 & Ensenada, B.C., Mexico & Enteromorpha \\
& 177-M & 1964 & La Jolla, California, U.S.A. & Aquarium outflow \\
& $178-\mathrm{M}$ & 1964 & La Jolla, California, U.S.A. & Pelagophycus \\
N. putrida & $179-\mathrm{M}$ & 1964 & Split, Jugoslavia & Silt in harbour \\
N. leucosigma & $176-\mathrm{M}$ & 1964 & La Jolla, California, U.S.A. & Pelagophycus \\
& $180-\mathrm{M}$ & 1965 & Chinook, Washington, U.S.A. & Fucus in marsh
\end{tabular}

RESULTS

\section{Replacement of Tryptone by defined nutrients}

A strain of Nitzschia alba from Ensenada was used for preliminary studies; unfortunately it died out before a suitable medium was evolved. Subsequent studies were carried out on strain 177-M, from La Jolla. In the enriched sea-water medium used to isolate these diatoms, Tryptone (Difco) served as the source of organic carbon, although the $0.2 \mathrm{~g} .1$. used permitted only limited growth. Since lactate can be assimilated by many pennate diatoms for growth in darkness (Lewin \& Lewin, 1960), various concentrations of sodium lactate were tested in liquid sea-water medium with $\mathrm{KNO}_{3}$, $\mathrm{K}_{2} \mathrm{HPO}_{4}$ and Tryptone, each only $0.2 \mathrm{~g}$./1. Na lactate $(1 \cdot 0 \mathrm{~g}$. $/ 1$.) appreciably stimulated growth. In media containing lactate, the Tryptone could be replaced by a vitamin mixture. It was thus clear that the organisms could use nitrate as source of nitrogen for growth.

It was then possible to determine whether any growth factors were required, by replacing the sea water (used in all media described above) by a suitable solution of mineral salts. This was effective with the defined mineral basal medium described in Methods.

In this basal medium, supplemented with suitable concentrations of sodium lactate $\left(10 \mathrm{~g} . / \mathrm{l}\right.$.) and $\mathrm{KNO}_{3}(1.0 \mathrm{~g} . / 1$.$) , the vitamin mixture could be replaced by cobalamin$ $(1 \mu \mathrm{g} . / \mathrm{l})+$. thiamine $(1 \mathrm{mg} . / \mathrm{l}$ ) . 


\section{Nutrition of various strains of Nitzschia}

Defined media based on the foregoing studies were used to determine which vitamins were required and which organic substrates could be utilized for growth by various strains of apochlorotic Nitzschia species. The results are summarized in Table 2.

\section{TAXONOMY}

The classification of species within the vast genus Nitzschia is poorly established. Cleve-Euler (1952), following Grunow, distinguished 21 sub-genera, of which we are here concerned with the following six:

Sigmoideae; sigmoid in girdle view, more or less straight in valve view; keel median Sigmata; as above, but keel marginal

Lineares; straight, linear, keel somewhat displaced from median axis

Dissipatae; straight, lanceolate, keel somewhat displaced from median axis

Spathulatae; straight, a line on each side of the keel

Lanceolatae; straight, lanceolate, keel close to one edge of the valve.

There seems little doubt that our sigmoid form, $180-\mathrm{M}$, is identifiable as Nitzschia leucosigma Benecke. The valves, though straight in surface view, are sigmoid in girdle view, which is the usual aspect one sees when looking down on an agar surface on which these organisms are crawling (Pl. 1, fig. 3-5).

The other strains, divisible into two main types, are less easily assigned to species. None agrees exactly with the description by Benecke (1900), according to whom Nitzschia putrida belongs to the Dissipatae or, possibly, to the Spathulatae (although he did not see or illustrate paracarinal lines characteristic of the latter subgenus). Pringsheim (1951) seems to have erred in referring $N$. putrida to the Sigmata, since he makes no reference to sigmoid form in his material. Benecke's illustrations of $N$. putrida clearly show the raphe only slightly displaced from the median axis. In most respects, our strain 176-M from La Jolla (Pl. 1, fig. 2) agrees with Benecke's description, though the organisms are considerably shorter (see Table 3). In view of the linear form of the valves, it would also be reasonable to assign this strain to the subgenus Lineares.

Our other isolates from La Jolla, however, like those from Woods Hole, Ensenada and Split, differ in the following features:

(a) The living organisms are more highly refractile by phase-contrast microscopy.

(b) In girdle view, the intact organisms are considerably thicker, about 5-6 $\mu$; compare $2-4 \mu$ for $N$. putrida $176-\mathrm{M}$.

(c) The cleaned valves are lanceolate, or, in the case of the shorter organisms, ovate, occasionally with a slight median constriction; compare our $N$. putrida 176-M, which has more or less straight sides.

(d) There is a clearly evident central nodule, where the two median puncta are spaced further apart then elsewhere (Pl. 1, fig. 3). Our N. putrida 176-M, like Benecke's illustrations of this species, lacks a central nodule.

(e) The position of the raphe is normally close to one margin of the valve. Our $N$. putrida 176-M, as in Benecke's illustration, has the raphe usually about one-third of the way across the valve.

This last character, in particular, seems to set apart our ovate-lanceolate forms in a 


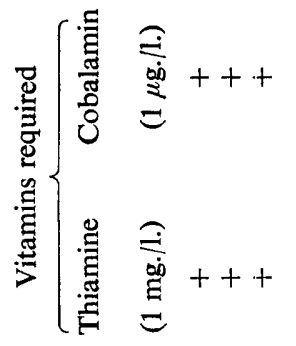

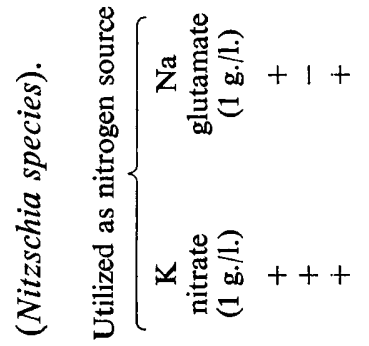

$\frac{2}{5}$

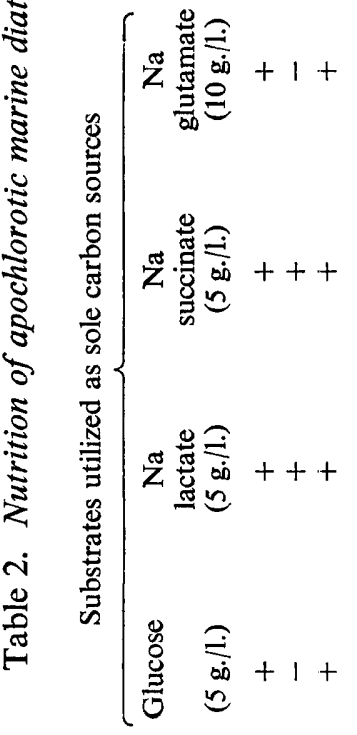

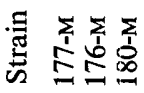

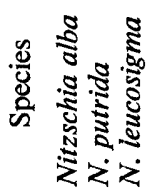

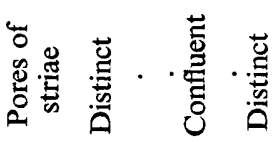

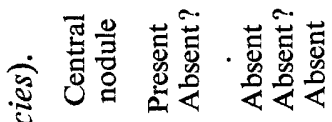

क्ष

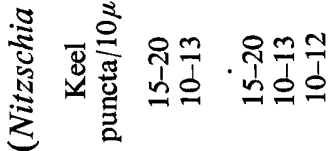

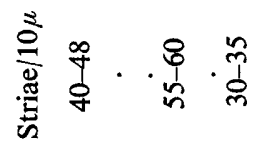

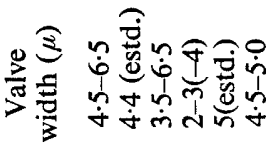

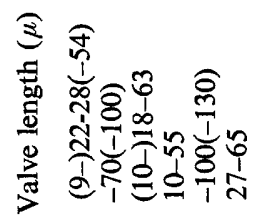

ธัँ

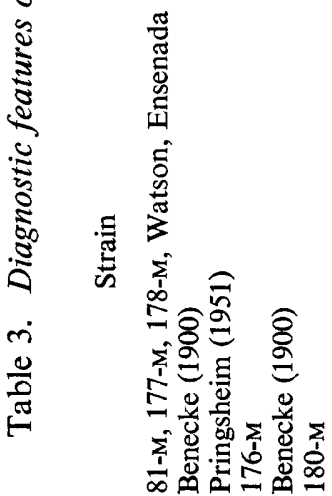

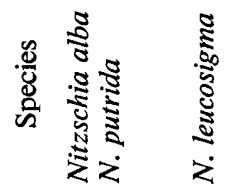


distinct subgenus the Lanceolatae. As far as we can determine, on the basis of the structure of their silica valves alone, our forms cannot be distinguished from Nitzschia laevis as described in the literature: form \pm apiculate, length $12-25 \mu$, width $5-7 \mu$, puncta $10-14 / 10 \mu$, striae imperceptible by light microscopy (Hustedt, 1939). We are fortunate in having for direct comparison two clones of normally pigmented marine diatoms which we have previously identified as $N$. laevis (Lewin \& Lewin, 1960). In the fine structure of the valves, our new apochlorotic species closely resembles $N$. laevis (our strain 72-M), though in the former the striae are somewhat coarser (44/10 $\mu$; compare $52 / 10 \mu$ for $N$. laevis). The question may be raised whether in 'cleaned' material, where the organic contents of the valves have been destroyed by heat or acid, it would be possible to distinguish between these two species. But we are inclined to agree with Benecke (1900) that loss of pigment must be regarded as constituting a specific character, if not indeed of generic importance (see Discussion).

A formal description in Latin follows.

\section{Nitzschia alba spec.nov.}

Subgenus: Lanceolatae. (Carina praeter aut prope marginem; valvae, lateraliter vistae, directae).

Cellulae sine chlorophyllo; mobiles; longae 9-54 $\mu$, amplae 4.5-6.5 $\mu$. Valvae lanceolatae sive aliquantum ellipsoides, aliquae in medio laeviter constrictae. Striae, manifestae solum a E-M, 44 in $10 \mu$, ordinum transversalium punctorum, diametro 120-200 nm compostae. Puncta carinae (inter claustra cognita a E-M) 13 in $10 \mu$, multa per axe elongata, 2-3 strias opponentes. Raphe (a E-M vista) in nodo centrale interrupta.

Hab. In algis lutoque litorum Adriaticae, Atlantici (Novae Angliae), Pacifici (Californiae), etc.

\section{DISCUSSION}

It seems clear that at least three distinct colourless species of Nitzschia occur in association with decaying seaweeds and other organic debris on temperate shores. (No apochlorotic diatom has been reported from a freshwater habitat, to the best of our knowledge.) The three species are distinguishable from one another not only by structural criteria, in the conformation of the siliceous shells, but also by physiological characters, notably in their different abilities to utilize exogenous sources of organic carbon for heterotrophic growth. Like many other heterotrophic microbes and like some photosynthetic diatoms (Lewin \& Lewin, 1960), they require exogenous sources of thiamine and cobalamin.

We may speculate on the phylogenetic origin of these apochlorotic diatoms. It is reasonable to suppose that they originated as non-photosynthetic mutants of photosynthetic, normally pigmented strains, capable of rapid growth in the presence of organic substrates. They would presumably have to reproduce rapidly, in order to succeed in such environments in competition with other heterotrophic organisms such as bacteria and fungi. It is noteworthy that all of these apochlorotic diatoms grow considerably more rapidly than do any of the normally pigmented diatoms so far studied under heterotrophic conditions. Nitzschia alba may have arisen from a pigmented ancestor such as $N$. laevis, which it closely resembles in shell detail, and which was likewise shown to be capable of heterotrophic growth in media containing either 
glucose or lactate (Lewin \& Lewin, 1960). However, neither of our $N$. laevis strains required an exogenous source of vitamins, as do the apochlorotic species studied here. $N$. putrida resembles $N$. angularis in details of its silica valves; however, $N$. angularis can utilize glucose but not lactate (Lewin \& Lewin, 1960), whereas $N$. putrida utilizes lactate but not glucose. As pointed out by Benecke (1900), $N$. leucosigma has many structural features in common with the pigmented species $N$. sigma; however, we have no information on the heterotrophic faculties of this last species, pure cultures of which have not yet been isolated.

We have considered, and rejected, the advisability of creating a special subgenus, with a name such as 'Hyalonitzschia', analogous to apochlorotic homologues of the green algae Raphidium (Hyaloraphidium), Chlorogonium (Hyalogonium), etc. In the case of the diatoms, where so much taxonomic emphasis is placed on the structure of the siliceous valves, it would probably be impractical at present to introduce other kinds of criteria. Furthermore, such a subgeneric distinction would cut across already existing subgeneric lines, based on structural features of the shells, which currently separate $N$. alba, N. putrida and N. leucosigma, respectively, in the subgenera Lanceolatae, Dissipatae and Sigmata.

We thank Dr S. M. Watson, Oceanographic Institution, Woods Hole, Mass., U.S.A., for first drawing our attention to an apochlorotic Nitzschia of doubtful identity; to Dr B. E. Reimann and Mrs Annika Sanfilippo, of the Scripps Institution of Oceanography, La Jolla, California, for the micrographs; and to the U.S. National Science Foundation, for financial support (to J.L.) under grant no. GB-4462.

This is a Contribution from the Scripps Institution, University of California, and from the Department of Oceanography, University of Washington (Contribution no. 413).

Permanent slide mounts and dried specimens of the cleaned silica walls of each of the three species discussed in this paper are being deposited in the California Academy of Sciences, San Francisco, and at the Smithsonian Institution, Washington, D.C., U.S.A.

\section{REFERENCES}

BENECKE, W. (1900). Uber farblose Diatomeen der Kieler Föhrde. Jahrb. wiss. Bot. 35, 535.

Cleve-Euler, A. (1952). Die Diatomeen von Schweden und Finnland. 3. K. Svenska Vetenskapsakad. Handl., Fjärde Serien. 3 (3).

Hustedt, F. (1939). Die Diatomeenflora des Küstengebietes der Nordsee vom Dollart bis zur Elbemündung. Abh. Naturwiss. Verein zu Bremen 31, 572.

LEwIN, J. C. \& LEwIN, R. A. (1960). Auxotrophy and heterotrophy in marine littoral diatoms. Can.J. Microbiol. 6, 127.

Pringsheim, E. G. (1951). Über farblose Diatomeen. Arch. Mikrobiol. 16, 18.

Pringsheim, E. G. (1956). Microorganisms from decaying seaweed. Nature, Lond. 178, 480.

Pringsheim, E. G. (1963). Farblose Algen. Stuttgart: Fischer Verlag.

RICHTER, O. (1909). Zur Physiologie der Diatomeen. II. Die Biologie der Nitzschia putrida Benecke. Denkschr. Akad. Wiss. Wien, Math-naturw. Kl. 84, 675.

WAGNER, J. (1934). Beiträge zur Kenntnis der Nitzschia putrida Benecke, insbesondere ihrer Bewegung. Arch. Protistenk. 82, 86. 


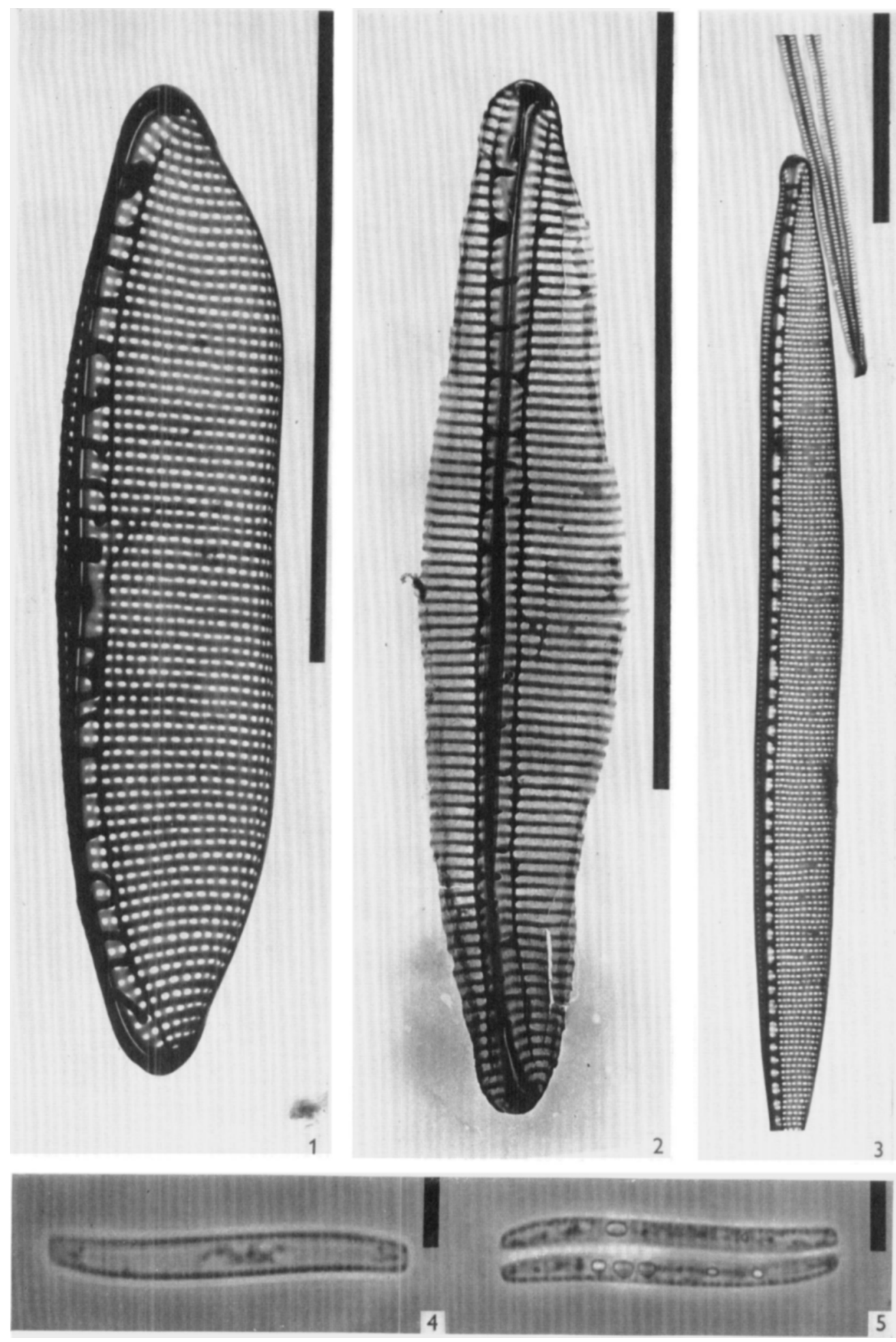


EXPLANATION OF PLATE

Scale bar $=10 \mu$ in each photograph.

Fig. 1. Nitzschia alba strain 178-M.

Fig. 2. Nitzschia putrida strain 176-M.

Fig. 3. Nitzschia leucosigma strain 180-M. Acid-cleaned valves; electron micrographs by Dr B. E. Reimann.

Fig. 4. Nitzschia leucosigma strain 180-M. Single organism.

Fig. 5. Nitzschia leucosigma strain 180-M. Pair of sister organisms. Living material; phase-contrast micrographs by Mrs Annika Sanfilippo. 